\title{
ISOLATION, CHARACTERIZATION, AND APPLICATION OF BACTERIOPHAGES AGAINST SEVERAL FOOD SPOILAGE BACTERIA: Bacillus subtilis, Bacillus cereus, AND Shewanella Putrefaciens
}

\author{
Felicia Roseline Sujonoputri ${ }^{1}$, Diana Elizabeth Waturangi $^{{ }^{*}}$, Yogiara $^{l}$ \\ Address (es): \\ ${ }^{1}$ Atma Jaya Catholic University of Indonesia, Faculty of Biotechnology, Department of Biotechnology, Jl. Jendral Sudirman No. 51, Jakarta 12930.
}

*Corresponding author: diana.waturangi@atmajaya.ac.id

Corresponding author: diana.waturangi@a atmaja.ac.id

https://doi.org/10.36547/be.263

\section{ABSTRACT}

Introduction: Bacteriophages can be the natural alternative method to prevent food spoilage caused by bacteria. This research was conducted to isolate bacteriophages from a soil sample, retail food, and wastewater from fish and then the bacteriophages will be characterized for their activity against several food spoilage bacteria, such as Bacillus cereus, Bacillus subtilis, and Shewanella putrefaciens and will be further investigated for application as food preservation.

Experimental: B. cereus (Atma Jaya culture collection), B. subtilis ATCC 6633, and S. putrefaciens ATCC 8071 were used for bacteriophage isolation. Food samples (rice, pasta, tofu, tempeh), soil samples (black soil and laterite), and wastewater sample of freshwater fish and seawater fish were used in this research. The overall process consists of eight steps: inoculum preparation, sample collection, bacteriophage isolation, purification and enrichment, titer determination, host range determination, the efficiency of plating (EOP), and bacteriophage application.

Results: A total of four bacteriophages were isolated with B. cereus, B. subtilis, and S. putrefaciens as host bacteria. Bacteriophage titers observed around $10^{9} \mathrm{PFU}$ mL ${ }^{1}$. Bacteriophages that isolated with B. cereus and B. subtilis as host bacteria tend to have high EOP with the same species bacteria. All the Bacillus phages (S1-BC, S2BC, and S1-BS) can reduce the Bacillus species bacteria concentration for more than $90 \%$.

Conclusion: Refers to their activity, the isolated bacteriophages in this study might have a great prospect to be used as food biocontrol and also can be further tested to make a phage cocktail.

Keywords: Agar overlay assay, Bacteriophages, Bacillus cereus, Bacillus subtilis, Food biocontrol, Shewanella putrefaciens

\section{INTRODUCTION}

Food spoilage is a metabolic process that causes changes in sensory characteristics, such as off-odor, textural changes, and visible growth of the colony in food. This spoilage is mediated by microbes that use food as their carbon and energy source. Some microbes are commonly found in many spoiled foods such as Bacillus cereus, Bacillus subtilis, and Shewanella putrefaciens (Rawat, 2015).

B. cereus has been recognized as a cause of food-borne disease and also known as a food spoilage agent. The proteolytic and lipolytic properties from these bacteria can affect the sensory characteristics from food for example sweet coagulation of milk and cream, ropy pastries (Jessberger $\boldsymbol{e t}$ al., 2020). The prevalence of $B$. subtilis in food products related to food spoilage has received little attention and only limited information is available. However, several studies have showed that $B$. subtilis can produce enterotoxins and emetic toxins resulting in food contamination (Krasowska et al., 2015). S. putrefaciens can cause the spoilage in both fresh and packed fish leads to off-odors even at the low cell numbers of bacteria. S. putrefaciens can produces trimethylamine (TMA), hydrogen sulphide $\left(\mathrm{H}_{2} \mathrm{~S}\right)$, methyl mercaptan $\left(\mathrm{CH}_{3} \mathrm{SH}\right)$, dimethyl sulphide $\left(\left(\mathrm{CH}_{3}\right)_{2} \mathrm{~S}\right)$, and other compounds resulting in intensive off-odors (Yang $\boldsymbol{e t}$ al., 2019).

Food preservation is usually done by physical or chemical method. However, these methods have been known to reduce the sensory or organoleptic properties of the food products. Preservation using an excessive amount of antibiotic can increase the antibiotic resistance capability in bacteria which give a negative impact on human antibacterial treatment (Thapar and Garcha, 2017).

Bacteriophages as the natural alternative method to prevent food spoilage is very promising to be used. Several publications reported that bacteriophages have gained great attention as food preservation because they are viruses that can targeting bacteria specifically to disrupt bacterial metabolism and can cause bacteria to lyse without disrupting human, animal, or plant cells (Yang et al., 2019). It can be isolated from a wide range of foods, such as rice, fish products, meat products, dairy products, fermented foods, and from soil (Oh et al., 2017; Yang et al., 2019). For food preservation, bacteriophage must be lytic type and non-transducing as the minimum requirements for ensuring safety (FDA, 2006). Bacteriophage can be formed into phage cocktail which can be used to prevent bacteriophage-resistant bacteria mutants (Mirzaei and Nilsson, 2015).

This research aimed to isolate and characterize lytic bacteriophages for B. cereus, $B$. subtilis, and $S$. putrefaciens from a soil sample, retail food, and wastewater from fish and analyze their capability as food biocontrol.

\section{MATERIAL AND METHODS}

The overall process in this research consists of eight steps including: bacterial strains preparation, sample collection, bacteriophage isolation, purification and enrichment, titer determination, host range determination, efficiency of plating (EOP), and bacteriophage application. In this research, mostly all the steps were done using the agar overlay assay method (Adams, 1959).

\section{Inoculum Preparation}

B. cereus from Atma Jaya culture collections, B. subtilis ATCC 6633, and S. putrefaciens ATCC 8071 were used in this study. Bacterial cultures were inoculated onto Luria agar (LA) and incubated at $37^{\circ} \mathrm{C}$ and $28^{\circ} \mathrm{C}$ (for $S$. putrefaciens) overnight.

\section{Sample Collection}

Different types of food samples (rice, pasta, tofu, tempeh), black soil (S1), laterite soil (S2), and wastewater samples of freshwater fish (SF) and seawater fish (SW) were collected in Jakarta, Indonesia.

\section{Bacteriophage Isolation for B. cereus and B. subtilis}

The bacterial host strain was grown at $37^{\circ} \mathrm{C}$ overnight at $120 \mathrm{rpm}$. Six grams of sample and $300 \mu \mathrm{L}$ of bacteria culture were added into $30 \mathrm{~mL}$ of Luria broth (LB) and then incubated at $37^{\circ} \mathrm{C}$ overnight at $150 \mathrm{rpm}$. The medium was centrifuged at $6300 \mathrm{x}$ g for 15 minutes and filtered using a $0.2 \mu \mathrm{m}$ syringe filter. The filtrate was centrifuged again at $6300 \mathrm{x}$ g for 10 minutes to make sure the filtrate was clean and tested for the presence of bacteriophages using the agar overlay assay (Adams, 1959; Oh et al., 2017).

\section{Bacteriophage Isolation for S. putrefaciens}

The bacterial host strain was grown to the mid-log phase at $28^{\circ} \mathrm{C}$ overnight at $120 \mathrm{rpm}$. Then, $30 \mathrm{~mL}$ of each wastewater sample was centrifuged at $6300 \mathrm{x} \mathrm{g}$ for 10 minutes and then filtered using a $0.45 \mu \mathrm{m}$ syringe filter. Subsequently, 5 $\mathrm{mL}$ of filtrate was mixed with $100 \mu \mathrm{L}$ of host bacteria and added into $5 \mathrm{~mL}$ of $2 \mathrm{X}$ $\mathrm{LB}$ then incubated at $28^{\circ} \mathrm{C}$ overnight. The culture was centrifuged at $6300 \mathrm{x}$ g for 10 minutes and filtered using a $0.2 \mu \mathrm{m}$ syringe filter. After that, $10 \mu \mathrm{L}$ of the filtrate was mixed with $100 \mu \mathrm{L}$ of host bacteria and then mixed it in $3 \mathrm{~mL}$ of soft agar and poured onto LA plate according to the agar overlay assay (Adams, 1959). 


\section{Bacteriophage Purification and Enrichment}

Phages were purified by removing a single plaque using a sterile tip onto the micropipette. The plaque was transferred into $500 \mu \mathrm{L}$ of SM buffer $(50 \mathrm{mM}$ Trishydrochloride (Tris- $\mathrm{HCl}$ ) [pH 7.5], $0.1 \mathrm{M} \mathrm{NaCl}, 8 \mathrm{mM}$ magnesium sulphate heptahydrate $(\mathrm{MgSO} 4 \cdot 7 \mathrm{H} 2 \mathrm{O})$, and $0.01 \%(\mathrm{w} / \mathrm{v})$ gelatine) and then vortexed. The plaque was then diluted with a 10 -fold serial dilution $(100 \mu \mathrm{L}$ of phages: $900 \mu \mathrm{L}$ of SM buffer). After that, $400 \mu \mathrm{L}$ of bacteria culture was mixed with $100 \mu \mathrm{L}$ of the respective phage dilutions. The phage-host mixture was incubated at $37^{\circ} \mathrm{C}$ and $28^{\circ} \mathrm{C}$ (for $S$. putrefaciens) to ensure phage adsorption to the host bacteria. Phages were plated according to the agar overlay assay (Adams, 1959; Gencay et al., 2016)

\section{Bacteriophage Titer Determination}

A series of 10-fold dilutions with SM buffer were made of bacteriophage lysate solution up to $10^{-8} .100 \mu \mathrm{L}$ of diluted bacteriophage solution was mixed with 100 $\mu \mathrm{L}$ of mid-log phase bacteria culture in $3 \mathrm{~mL}$ of soft agar. The soft agar mixture was then poured onto the agar and incubated at $37^{\circ} \mathrm{C}$ and $28^{\circ} \mathrm{C}$ (for $S$. putrefaciens) overnight. The number of visible plaques was counted between 30 to 300 plaques and calculated as plaque-forming unit (PFU) $\mathrm{mL}^{-1}$ (Gencay et al., 2016).

\section{Host Range Determination}

Two Escherichia coli pathotypes (EHEC and EPEC), Vibrio cholerae, B. cereus, and $B$. subtilis were tested for susceptibility towards isolated bacteriophages. Briefly, $100 \mu \mathrm{L}$ of bacteriophage solution was mixed with $100 \mu \mathrm{L}$ of tested bacteria in $3 \mathrm{~mL}$ of soft agar. The mixture was then poured on top of agar and incubated at $37^{\circ} \mathrm{C}$ and $28^{\circ} \mathrm{C}$ (for S. putrefaciens) overnight (Sufa et al., 2018).

\section{Efficiency of Plating (EOP)}

Bacteriophages that can lyse the tested bacteria in the host range determination method were continued to the EOP. The EOP was calculated by dividing the average PFU of target bacteria by the average PFU of host bacteria (Mirzaei and Nilsson, 2015).

\section{Bacteriophage Application}

Rice and pasta sample were sterilized for 15 minutes at $121^{\circ} \mathrm{C}$. Tested bacteria (B. cereus, B. subtilis, V. cholerae) were inoculated $10^{4}$ colony-forming unit (CFU) $\mathrm{cm}^{-2}$ onto the surface of the food surface followed by phage application at concentration $10^{9} \mathrm{PFU} \mathrm{\textrm {mL } ^ { - 1 }}$ (S1-BC, S2-BC, and S1-BS). Samples were incubated at $25^{\circ} \mathrm{C}$ overnight. For the control, the same volume of SM buffer was used instead of phage (Hyman, 2019). Samples were suspended with $9 \mathrm{~mL}$ of SM buffer. A 10-fold serial dilution was made then spread onto the LA plate and incubated at $37^{\circ} \mathrm{C}$ overnight. The appropriate dilutions giving number colony between 30 to 300 colonies were expressed as CFU mL ${ }^{-1}$ (Shin et al., 2011).

\section{RESULTS AND DISCUSSION}

\section{RESULTS}

\section{Bacteriophage Isolation}

Three bacteriophages could be isolated from two types of soil, which is black soil and laterite soil (S1-BC, S2-BC, and S1-BS). One bacteriophage can be isolated from the wastewater of seawater fish (SW-SP). All positive results were classified as lytic bacteriophages due to the clear zone plaques on top of agar.

\section{Bacteriophage Titer Determination}

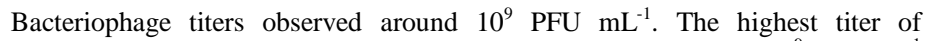
bacteriophage was from S2-BC isolate with a titer of $1.84 \pm 0.17 \times 10^{9} \mathrm{PFU} \mathrm{mL}^{-1}$ (Tab 1).
Table 1 Titer determination of isolated bacteriophages

\begin{tabular}{lc}
\hline Bacteriophage Isolate & Titer $\left(\mathbf{P F U} \mathbf{~ m L}^{-\mathbf{1}}\right)$ \\
\hline S1-BC & $1.51 \pm 0.13 \times 10^{9}$ \\
S2-BC & $1.84 \pm 0.17 \times 10^{9}$ \\
S1-BS & $1.33 \pm 0.10 \times 10^{9}$ \\
SW-SP & $1.78 \pm 0.06 \times 10^{9}$ \\
\hline
\end{tabular}

S1 = Soil 1 (Black soil); S2= Soil 2 (Laterite soil); SW= Seawater

$\mathrm{BC}=B$. cereus $; \mathrm{BS}=B$. subtilis $; \mathrm{SP}=S$. putrefaciens

\section{Host Range Determination and EOP}

Bacteriophages isolated with B. cereus as host bacteria could lyse B. subtilis, and vice versa. All the bacteriophages couldn't lyse different species of bacteria such as EHEC, EPEC, and V. cholerae. The S1-BC, S2-BC, and S1-BS bacteriophage showed high infection effectivity with EOP more than 0.5. The plating on the original strain of isolation resulted in EOP $=1.0(\mathrm{Tab} 2)$.

Table 2 Bacteriophages efficiency of plating (EOP)

\begin{tabular}{lccccc}
\hline \multirow{2}{*}{ Bacteriophage Isolate } & \multicolumn{6}{c}{ Efficiency of Plating } \\
& BC & BS & EHEC & EPEC & VC \\
\hline S1-BC & 1.0 & 2.14 & - & - & - \\
S2-BC & 1.0 & 1.89 & - & - & - \\
S1-BS & 0.93 & 1.0 & - & - & - \\
SW-SP & - & - & - & - & - \\
\hline
\end{tabular}

\section{Bacteriophage Application}

Pasta and rice were artificially contaminated with host bacteria to calculate bacteria reduction if samples were added with bacteriophages. S1-BC, S2-BC, and S1-BS bacteriophages significantly reduced bacterial concentration in samples by more than $90 \%$. However, no significant reduction was observed when samples with S1-BC, S2-BC, and S1-BS bacteriophages were tested against V. cholerae. (Tab 3).

\section{DISCUSSION}

In this study, phages that were isolated from soil samples can invade B. cereus and $B$. subtilis; also, bacteriophage that was isolated from wastewater of seawater fish can invade $S$. putrefaciens as their host bacteria. These isolated phages could be classified as lytic type phages based on the clear zone plaques that appeared on top of the agar (Sufa $\boldsymbol{e t}$ al., 2018). However, no phages could be obtained from food samples (tofu, tempeh, pasta, rice) and also wastewater of freshwater fish. This might be due to the food samples used in this study are processed foods so the processing method can affect the presence of host bacteria and due to different environment and interaction of biotic and abiotic components (Oh et al., 2017; Thung et al., 2017).

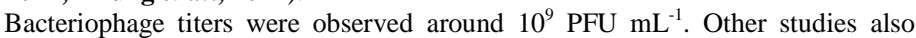
showed a similar result with bacteriophage titers observed $>10^{8} \mathrm{PFU} \mathrm{mL}{ }^{-1}$ which can be used for further analysis of the bacteriophage (Shin et al., 2011). Bacteriophage titer determination is needed to prevent higher bacteria concentration than the phage concentration for further analysis such as bacteriophage application (Klasse, 2015).

Phages that were isolated in this study are specific so they couldn't attack other bacteria with different species. A host range that is limited to a single species is desirable because it prevents the phage from killing other species of bacteria and leaving the rest of the host's microbiome intact (Hyman, 2019). Each bacteriophage has different tail fibers with receptor binding protein (RBP) that can bind to specific receptor on the host bacteria surface. Each host bacteria cell wall also has different components and additional constraints (Hyman, 2019).

The EOP method was done to determine which phage was the most effective in killing other bacteria. In this study, all the phages tested for EOP (S1-BC, S2-BC, and S1-BS) were indicated to be highly effective with EOP $\geq 0.5$. EOP between any phage pair may vary with different host bacteria, it can be affected by the host resistance system and the absorption of phage into host cells (Hyman, 2019). High results of EOP bacteriophage might be useful for further research to make a bacteriophage cocktail (Mirzaei and Nilsson, 2015). 
Based on the results, all the Bacillus phages (S1-BC, S2-BC, S1-BS) reduced $B$. cereus and B. subtilis efficiently. The higher concentration of phages has a correlation with the efficiency of the bacteriophage application process to lyse targeted bacteria (Guenther et al., 2009). However, different results were found when the Bacillus phages were applied against $V$. cholerae. The reason why $V$. cholerae was added in this method because it is known that $V$. cholerae also can survive on cooked rice and pasta for up to 5 days and can multiply rapidly at ambient temperature (Maheshwari et al., 2011; Tang et al., 2013). This result was related to the host range determination result where phages can't lyse other species of bacteria. The reduction of bacteria can be affected by the food texture and matrix to absorb the phages' suspension and the distribution of phages in food samples (Fister et al., 2016). Phages' growth also depends on their ability to diffuse and contact with the host bacteria. The effectivity will lower due to limited diffusion and contact with the host bacteria. This is also influenced by differences in receptors between phages and host bacteria (Hyman, 2019).

This research discovers the effectiveness of bacteriophage against food spoilage bacteria and based on the results of this research, bacteriophages can be applied further and be beneficial for improving the quality of the products in the food industry. This research will help the researcher to uncover the critical areas of preventing food spoilage process that many researchers were not able to explore. Thus, a new theory on these phage application and phage cocktail combination may be arrived at. This research was only carried out until bacteriophage application with Bacillus phages, thereby authors recommend that further research needs to be conducted to determine the food application of $S$. putrefaciens phages, the minimum inhibitory multiplicity of infection, and also the morphology of isolated phages.

Table 3 Bacteriophages application on pasta and rice

\begin{tabular}{|c|c|c|c|c|c|c|}
\hline $\begin{array}{l}\text { Bacteriophage } \\
\text { Isolate }\end{array}$ & Food Sample & $\begin{array}{c}\text { Tested } \\
\text { Bacteria }\end{array}$ & $\begin{array}{c}\text { Control (CFU } \\
\left.\mathbf{m L}^{-1}\right)\end{array}$ & $\begin{array}{c}\text { Bacteriophage } \\
\text { treatment (CFU } \\
\left.\mathrm{mL}^{-1}\right)\end{array}$ & $\begin{array}{c}\text { Bacteria } \\
\text { reduction } \\
(\log )\end{array}$ & $\begin{array}{c}\text { Bacteria } \\
\text { reduction } \\
(\%)\end{array}$ \\
\hline \multirow{6}{*}{ S1-BC } & \multirow{3}{*}{ Pasta } & B. cereus & $3.60 \times 10^{8}$ & $3.60 \times 10^{5}$ & 3.00 & 99.90 \\
\hline & & B. subtilis & $4.50 \times 10^{8}$ & $3.80 \times 10^{5}$ & 2.98 & 99.89 \\
\hline & & V. cholerae & $3.10 \times 10^{8}$ & $2.01 \times 10^{8}$ & 0.19 & 35.16 \\
\hline & \multirow{3}{*}{ Rice } & B. cereus & $4.00 \times 10^{8}$ & $2.10 \times 10^{5}$ & 3.28 & 99.95 \\
\hline & & B. subtilis & $4.70 \times 10^{8}$ & $3.80 \times 10^{5}$ & 3.09 & 99.92 \\
\hline & & V. cholerae & $4.20 \times 10^{8}$ & $2.35 \times 10^{8}$ & 0.25 & 44.05 \\
\hline \multirow{6}{*}{ S2-BC } & \multirow{3}{*}{ Pasta } & B. cereus & $3.60 \times 10^{8}$ & $3.20 \times 10^{5}$ & 3.05 & 99.91 \\
\hline & & B. subtilis & $4.50 \times 10^{8}$ & $2.30 \times 10^{5}$ & 3.19 & 99.94 \\
\hline & & V. cholerae & $3.10 \times 10^{8}$ & $1.93 \times 10^{8}$ & 0.20 & 37.74 \\
\hline & \multirow{3}{*}{ Rice } & B. cereus & $4.00 \times 10^{8}$ & $3.50 \times 10^{5}$ & 3.06 & 99.91 \\
\hline & & B. subtilis & $4.70 \times 10^{8}$ & $2.40 \times 10^{5}$ & 3.29 & 99.95 \\
\hline & & V. cholerae & $4.20 \times 10^{8}$ & $2.71 \times 10^{8}$ & 0.19 & 42.34 \\
\hline \multirow{6}{*}{ S1-BS } & \multirow{3}{*}{ Pasta } & B. subtilis & $4.50 \times 10^{8}$ & $2.00 \times 10^{5}$ & 3.35 & 99.96 \\
\hline & & B. cereus & $3.60 \times 10^{8}$ & $3.10 \times 10^{5}$ & 3.06 & 99.91 \\
\hline & & V. cholerae & $3.10 \times 10^{8}$ & $1.91 \times 10^{8}$ & 0.21 & 38.39 \\
\hline & \multirow{3}{*}{ Rice } & B. subtilis & $4.70 \times 10^{8}$ & $2.50 \times 10^{5}$ & 3.27 & 99.94 \\
\hline & & B. cereus & $4.00 \times 10^{8}$ & $3.30 \times 10^{5}$ & 3.08 & 99.92 \\
\hline & & V. cholerae & $4.20 \times 10^{8}$ & $2.87 \times 10^{8}$ & 0.17 & 31.67 \\
\hline
\end{tabular}

\section{CONCLUSION}

Four type of lytic phages were successfully isolated from black soil, laterite soil, and wastewater of seawater fish with B. cereus, B. subtilis, and S. putrefaciens as the host bacteria. All of the isolated phages showed high titer concentrations for more than $1 \times 10^{9} \mathrm{PFU} \mathrm{mL}{ }^{-1}$. Phages isolated with B. cereus and B. subtilis as host bacteria tend to have high EOP and also can reduce the bacteria concentration effectively. All the isolated phages might have a great prospect to be used as food biocontrol and can be further tested to make phage cocktail.

Acknowledgements: The authors are grateful for all the support and everyone who have contributed in this study.

Funding: This research was partially sponsored by Ministry of Research and Technology / National Research and Innovation Agency of the Republic of Indonesia 2019-2020.

Conflict of Interest: The authors declare that they have no conflict of interest.

\section{REFERENCES}

Adams, M. H. (1959). Bacteriophages. (Edn 1). New Jersey: Interscience Publishers.

Fister, S., Robben, C., Witte, A. K., Schoder, D., Wagner, M., \& Rossmanith, P. (2016). Influence of environmental factors on phage-bacteria interaction and on the efficacy and infectivity of phage P100. Front Microbiol, 7, 1-13. http://dx.doi.org/10.3389/fmicb.2016.01152

Food and Drug Administration (FDA). (2006). Food additives permitted for direct addition to food for human consumption; bacteriophage preparation. Fed Regist, 71(160), 47729-47732.
Gencay, Y. E., Birk, T., Sørensen, M. C. H., Brøndsted, L. (2016). Methods for isolation, purification, and propagation of bacteriophages of Campylobacter jejuni. Methods in Molecular Biology, 1512, 19-28. http://dx.doi.org/10.1007/978-1-4939-6536-63

Guenther, S., Huwyler, D., Richard, S., Loessner, M. J. (2009). Virulent bacteriophage for efficient biocontrol of Listeria monocytogenes in ready-to-eat foods. Applied and Environmental Microbiology, 75(1), 93-100. http://dx.doi.org/10.1128/AEM.01711-08

Hyman, P. (2019). Phages for phage therapy: isolation, characterization, and host range breadth. Pharmaceuticals, 12(35), 1-23. http://dx.doi.org/10.3390/ph12010035

Jessberger, N., Dietrich, R., Granum, P. E., Märtlbauer, E. (2020). The Bacillus cereus food infection as multifactorial process. Toxins, 12(701), 1-37. http://dx.doi.org/10.3390/toxins12110701

Klasse, P. J. (2015). Molecular determinants of the ratio of inert to infectious virus particle. Prog. Mol. Biol. Transl. Sci., 129(1), 285-326. http://dx.doi.org/10.1016/bs.pmbts.2014.10.012

Krasowska, A., Biegalska, A., Augustyniak, D., Łoś, M., Richert, M., Łukaszewicz, M. (2015). Isolation and characterization of phages infecting Bacillus subtilis. BioMed Research International, 2015(179597), 1-10. http://dx.doi.org/10.1155/2015/179597

Maheshwari, M., Nelapati, K., Kiranmayi, B. (2011). Vibrio cholerae. Veterinary Word, 4(9), 423-428. http://dx.doi.org/10.5455/vetworld.2011.423-428

Mirzaei, M. K., Nilsson, A. S. (2015). Isolation of phages for phage therapy: a comparison of spot test and efficiency of plating analyses for determination of host range and efficacy. PLoS One, 10(3), 1-13. http://dx.doi.org/10.1371/journal.pone.011855 
Oh, H., Seo, D. J., Jeon, S. B., Park, H., Jeong, S., Chun, H. S., Oh, M., Choi, C. (2017). Isolation and characterization of Bacillus cereus bacteriophages from foods and soil. Food and Environmental Virology, 9, 260-269. http://dx.doi.org/10.1007/s12560-017-9284-

Rawat, S. (2015). Food spoilage: microorganisms and their prevention. Asian Journal of Plant Science and Research, 5(4), 47-56. https://www.imedpub.com/articles/food-spoilage-microorganisms-and-theirprevention.pdf

Shin, H., Bandara, N., Shin, E., Ryu, S., Kim, K. (2011). Prevalence of Bacillus cereus bacteriophages in fermented foods and characterization of phage JBP901. $\begin{array}{llll}\text { Research in } & \text { 162(2011), } & \text { 791-797. }\end{array}$ http://dx.doi.org/10.1016/j.resmic.2011.07.001

Sufa, H. I., Budiarti, S., Rusmana, I. (2018). Diversity of uropathogenic Escherichia coli lytic phage from cisadane river, west java, Indonesia based on morphology and protein molecular weight characteristics. Biodiversitas, 19(6), 2359-2364. http://dx.doi.org/10.13057/biodiv/d190646

Tang, J. Y. H., Izenty, B. I., Izzati, A. J. N., Masran, S. R., Yeo, C. C., Roslan, A., Bakar, C. A. A. (2013). Survivability of Vibrio cholerae O1 in cooked rice, coffee, and tea. International Journal of Food Science, 2013(581648), 1-5. http://dx.doi.org/10.1155/2013/581648

Thapar, P., Garcha, S. (2017). Incidence and characterization of Pseudomonas species isolated from spoilt fresh produce. Indian Journal of Experimental Biology, 55, 372-276. http://nopr.niscair.res.in/bitstream/123456789/42212/1/IJEB\%2055\%286\%29\%2 0372-376.pdf

Thung, T. Y., Norshafawatie, S. B. M. F., Premarathne, J. M. K. J. K., Chang, W. S., Loo, Y. Y., Kuan, C. H., New, C. Y., Ubong, A., Ramzi, O. S. B., Mahyudin, N. A., Dayang, F. B., Jasimah, W. M. R., Son, R. (2017). Isolation of food-borne pathogen bacteriophages from retail food and environmental sewage. IFRJ, 24(1), 450-454. http://www.ifrj.upm.edu.my/24\%20(01)\%202017/(59).pdf

Yang, Z. Q., Tao, X. Y., Zhang, H., Rao, S. Q., Gao, L., Pan, Z. M., Jiao, X. A. (2019). Isolation and characterization of virulent phages infecting Shewanella baltica and Shewanella putrefaciens, and their application for biopreservation of chilled channel catfish (Ictalurus punctatus). International Journal of Food Microbiology, 292(2019),

http://dx.doi.org/10.1016/j.ijfoodmicro.2018.12.020 